\title{
SIMULATION MODEL OF AIRCRAFT OPERATIONAL MAINTENANCE PROCESS IN FAILURE SITUATIONS
}

\author{
${ }^{1,2}$ Faculty of Transport, Management and Logistics, National Aviation University, Kyiv, Ukraine \\ E-mails: 1'dmitroshevchuk@gmail.com, ${ }^{2}$ medynskyi_denys@ukr.net \\ ${ }^{1}$ ORCID 0000-0001-9911-7214, ${ }^{2}$ ORCID 0000-0002-8081-8712
}

\begin{abstract}
The main elements of the queuing service system, which includes the ground handling system of aircraft, are the incoming flow of orders and the service subsystem. The service subsystem is a set of service devices, which are technical platform crews that are used in the technological processes of ground aircraft handling of in the system of aircraft ground handling. Objects of the simulation model of the aircraft ground handling, depending on the setting of outlined tasks, are divided into static and dynamic. Technological processes of aircraft ground handling are characterized by three features: the division of processes into operations, coordination and phasing, unambiguous actions. The purpose of the division of the process into operations is to determine the sections required from the executor. Any operation has to provide customising the control object due to the task and ensure the transition from one operation to another.
\end{abstract}

Index Terms - Simulation model; failure; decision making; aircraft ground handling.

\section{INTRODUCTION}

A small number of scientific works written by both Ukrainian and foreign authors have been devoted to the issue of modelling the process of aircraft ground handling. The work [1], in which the author proposes improving the method of interactive decision making by the dispatcher of integrated operational control of ground handling of aircraft, deals with the analysis of the aircraft ground handling system as an element of interaction between the airport and the airline in the air transport system. In her work [2] the author improves the technology of ground services for the smooth operation of the airport. The author [3] points to the prevention of errors caused by the human factor in the operation of air transport using information and management systems. But even today, the full list of simulation works that can be used in AGH has not been determined yet.

\section{Problem Statement}

Is to formalize the process of aircraft ground handling (AGH) system's functioning and to build a model of operational planning in the AGH management with the help of simulation modelling taking into consideration the quantitative indicators.

\section{PRoblem Solution}

To perform the work related to the preparation of aircraft for flight, the AGH system is formed at the airport. The main requirement for this system is to ensure the implementation of the daily flight plan (DFP), which in turn is a normative document depending on which the work of the AGH system is organized [4].

To solve this task successfully, the characteristics of the researched system AGH must meet the parameters of the input flow of the aircraft maintenance requirements contained in the AGH.

As such parameters it is necessary to investigate the aircraft type, the nature of the $i$ th flight, the volume of work $Q$ on aircraft maintenance, the scheduled time of arrival $t_{i_{\text {arrval }(\text { plan })}}$ and departure $t_{i_{\text {departure } \text { plan })}}$ of the aircraft. These data allow determining the sequence and technology of aircraft maintenance, the duration of individual operations $t_{i j}$ $\mathrm{t}_{i j}$ and the entire process of preparing $T_{\text {preparation }}$ the aircraft for flight, as well as the required number of airport resource units $m$, required to implement the production plan. At the same time, special attention is paid to the state of the $\mathrm{AGH}$ system, the availability of the required number of resource units and their efficiency.

The process of the AGH system's functioning is stochastic in nature, which in turn due to the influence of various random factors, which can be divided into two groups; external, related to the change in the nature of the incoming flow of aircraft service requirements, and internal, determined by the state of the ground base of the airport.

As a result of the influence of these factors, situations occur, the development of which can lead to a decrease in the level of regularity and security of the aircraft. These situations are considered to be 
freelance, despite the fact that they are quite typical for the airline. Aircraft ground handling planning is carried out for these situations [5].

The model of the process of the AGH system's functioning in an emergency situation when servicing an aircraft using a set of airport resources as shown in Fig. 1. This model simulates the introduction of two additional transit flights to the DFP, which is a change in the nature of the incoming flow of the aircraft service requirements. As a set of resources, we have considered all units of airport resources involved in the maintenance of a particular flight.

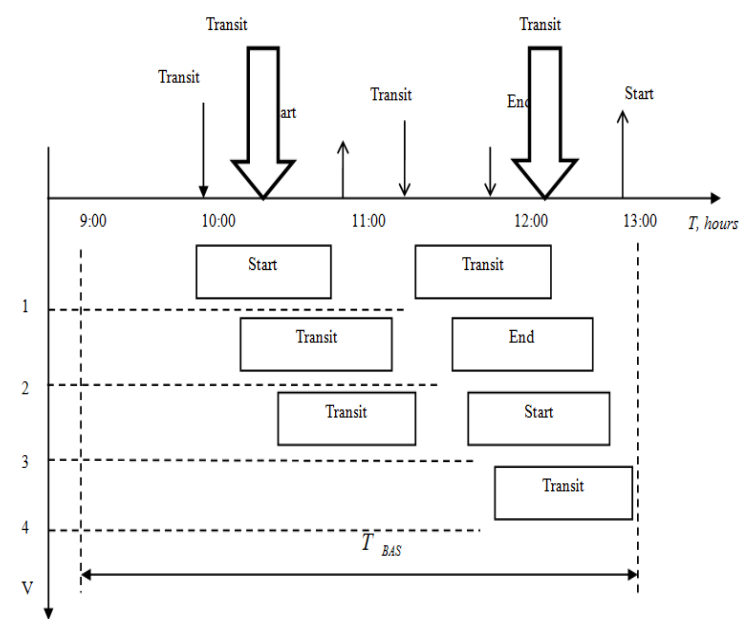

Fig. 1. Model of the process of the AGH system's functioning in an emergency situation while servicing an aircraft using a set of airport resources

It is impossible to ensure the implementation of the existing DFP without adjusting it with a smaller number of complexes. The aircraft ground handling system uses an additional set of resources for providing a way out of the emergency situation. Forming a new production plan of the airport leads to a change in the main indicators which characterize the functioning of the AGH system:

1) $V$ is the required amount of resources to be provided by the airport with timely maintenance $P_{i}$ of the aircrafts and DFP;

2) $T_{\text {duration }_{\text {ih }}}$ is the duration of aircraft ground handling, that performs the ith flight using the $h$ complex of airport resources;

3) $T_{\text {direct }_{h}}$ is the development of the $h$ complex of airport resources in the period of consideration of the emergency situation;

4) $T_{\text {direct }_{V}}$ is the total operating time of all complexes of resources of the $V$ airport in servicing the personal computer in the period of consideration of the emergency situation. In other words - the total duration of service of all flights provided by the DFP;
5) $T_{\text {downtime }_{h}}^{1}$ is the absolute duration of downtime of the $h$ complex of airport resources during the period under consideration;

6) $T_{\text {downtime }_{h}}^{2}$ is the duration of downtime of the $h$ complex of airport resources relative to the total operating time of all resource complexes $V$;

7) $K_{\text {direct }_{h}}^{1}$ is the coefficient of development of the $h$ complex of airport resources in relation to the period under consideration;

8) $K_{\text {direct }_{h}}^{2}$ is the coefficient of operating time of the $h$ complex of airport resources relative to the total operating time of all resource complexes $V$;

9) $K_{\text {downtime }_{h}}^{1}$ is the downtime coefficient of the $h$ complex of airport resources in relation to the period under consideration;

10) $K_{\text {downtime }_{h}}^{2}$ is the downtime coefficient of the $h$ complex of airport resources relative to the total operating time of all airport complexes $V$;

11) $m$ is the required number of units of each type of resources $f t h$, required for timely maintenance of the aircraft and the implementation of DFP;

12) $t_{\text {open }_{i j}}$ is the duration of use of the $j t h$ unit of resource at service of the aircraft which carries out the ith flight;

13) $T_{\text {direct }_{j}}$ is the duration of using the $j t h$ unit of resource when servicing aircrafts during the period under consideration;

14) $T_{\text {direct }_{f}}$ is the total duration of using the $f$ th type of resources in the maintenance of the aircraft in the period of consideration;

15) $T_{\text {downtime }}^{1}$ is the absolute duration of downtime of the $j$ th unit of resource in the period of consideration;

16) $T_{\text {downtime }_{j}}^{2}$ is the duration of idle $j$ th unit of resource relative to the total duration of use of the fth type of resources;

17) $K_{\text {direct }_{j}}^{1}$ is the coefficient of using $j$ th resource unit due to the period of consideration;

18) $K_{\text {direct }_{j}}^{2}$ is the coefficient of using $j t h$ resource unit according to the total duration of using of $f$ th type of resources;

19) $K_{\text {downtime }_{j}}^{1}$ is the downtime coefficient of $j t h$ resource unit due to a certain period under consideration;

20) $K_{\text {downtime }_{j}}^{2}$ is the downtime coefficient of $j$ th resource unit due to the total duration of using the fth type of resources. 
This condition implies the absence of the required number of units $m$ of each type of airport resources $f t h$ required to ensure timely maintenance of the aircraft and the implementation of DFP. The operation of the AGH system in such conditions leads to an emergency situation when the service of all flights provided by the DFP is impossible. The solution of this problem reveals in to adjusting the DFP and changing the start and end times of flight services so as to ensure that all technological work is performed thoroughly[6].

The main indicators of the effectiveness of the AGH system in an emergency situation were given above, but in this case we additionally use the following characteristics:

- $N_{\text {delay }_{P C}}$ is the number of delayed flights;

- $t_{\text {delay }_{i}}$ is the delay time of the ith flight, $\mathrm{h}$;

- $T_{\text {delay }_{\text {total }}}$ is the total delay time of all flights, $\mathrm{h}$.

To determine these characteristics, let us use the formulas:

$$
\begin{gathered}
t_{\text {delay }_{i}}=t_{\text {departure }_{(f a c t) i}}-t_{\text {departure }_{\left(\text {plan }_{i}\right)}}, \\
T_{\text {delay }_{P C}}=\sum_{i=1}^{N_{\text {delay } P C}} t_{\text {delay }_{i}} .
\end{gathered}
$$

These characteristics are used in the analysis of the emergency situation, determining the financial and material costs necessary to ensure the exit from it and compensation. Using the considered characteristics, the analysis of the process of functioning of the AGH system in an emergency situation is carried out in order to determine the degree of its reliability. Obviously, the following conditions are met for the reliable AGH system:

$$
t_{\text {delay }_{i}}=0, \quad N_{\text {delay }_{P C}}=0 .
$$

The model of the process of the AGH system's functioning in an emergency situation with a limited number of airport resources is presented in Fig. 2.

In this case, during the reviewed period, the limit on the number of the used sets of airport resources, namely the service of all flights provided by the DFP, should be carried out using two complexes. It is worth noting that the involvement of the third set of resources has been associated with the need in servicing the first flight, the departure time of which is 12 hours and 50 minutes. In order to fulfill the restriction, this flight's service must be performed using the first set of resources, but this is possible only after servicing the transit flight. Thus, the full service of the first flight is ensured only during the postponement of the flight departure time by 30 minutes compared to the scheduled time, which in turn should also be reflected in the DFP. Noteworthy is also the fact that in this case the planning of AGH solved the problem of allocating the optimal use of limited resources of the airport, which characterizes the process of functioning of the AGH system in an emergency situation [7].

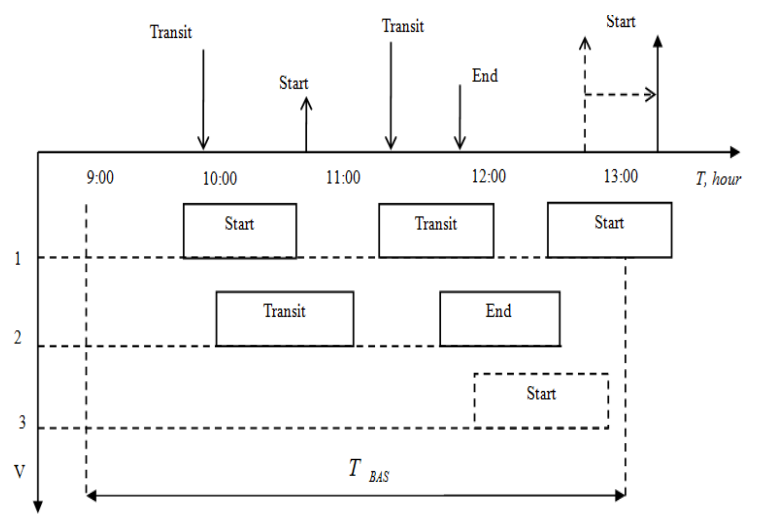

Fig. 2. Model of the AGH system's functioning in an emergency situation with a limited number of airport resources

Thus, the simulation model allows taking into consideration the state of the airport's ground base, which has an impact and limitations on the amount of resources used in the operation of the AGH system. In addition, the results of the application of this simulation model in the planning process of AGH can be used not only in the preparation of the production plan of the airport, but also in the formation of the schedule of aircrafts at the airport (DFP).

\section{RESULTS}

The process of functioning of the airport as the AGH system is stochastic. The greatest influence on this process has the nature of the incoming flow of requirements for aircraft maintenance, on the basis of which the production plan of the airport is formed. The nature of the input stream is determined by many different factors. The formation of the production plan of the airport is carried out taking into account the actual state of its ground base and the peculiarities of the functioning of the AGH system. The combination of adverse factors can lead to a situation where the AGH system will not be able to service the input flow of the requirement. If the production plans of the airport complex as a whole are violated, then this situation is considered a failure.

A failure situation is characterized by a violation of the schedule of air traffic, resulting in aircrafts and passengers accumulation at the airport. This definition characterizes the state of the air transport system as a whole, as it reflects only the external manifestation of the failure situation; the internal manifestation is 
associated with the failure of the entire AGH system. The occurrence of an emergency situation at the airport can be predicted, as the emergency situation is the development of an emergency situation. That is, the occurrence of a failure situation can be prevented by an appropriate influence on the AGH system in order to optimize the process of its functioning in real conditions. Thus, it enables ensuring the implementation of the DFP and the restoration of the characteristics of the air transport system. It should be noted that the impact on the AGH system can be both resource and information.

Failure can occur, for example, as a result of temporary closure of the airport. The closure of the airport is accompanied by a violation of the production plan of the AGH system. The model of the process of functioning of the AGH system in a failure situation when servicing an aircraft using the set of airport resources is presented in Fig. 3.

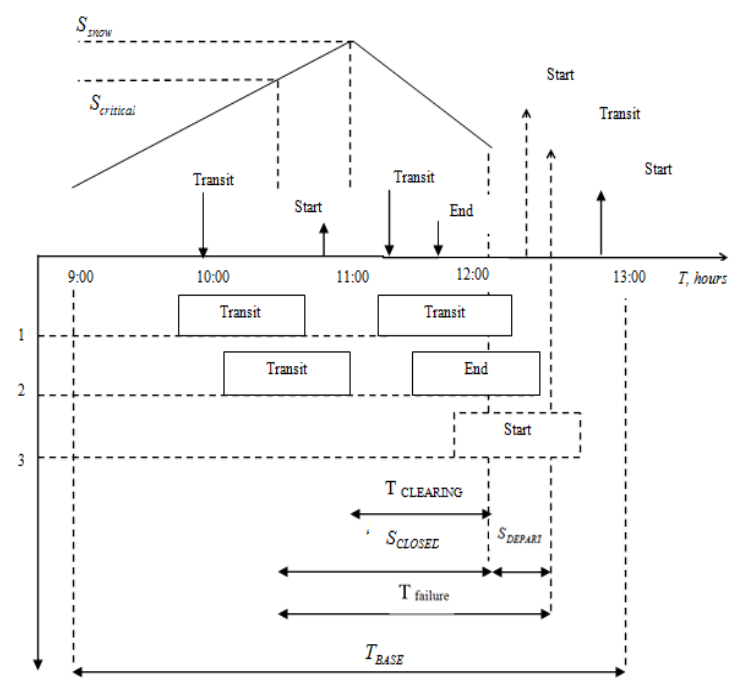

$V+d$, amount

Fig. 3. Model of the AGH system's functioning process in case of failure in the aircraft maintenance, taking into consideration the complex of airport resources: $S_{\text {snow }}$ is the snow cover thickness, which was formed as a result of precipitation during adverse weather conditions; $S_{\text {critical }}$ is the critical snow cover thickness, at which the airport is closed for the reception and departure of the aircraft, is

determined depending on the type of the aircraft

While modelling the process of the AGH system's functioning, we shall note that the arrival of all flights provided by the DFP is carried out until the airport is the closed, which occurred at 10 hours 30 minutes. It is obvious that the departure of all aircrafts which are at the airport is possible only after the opening of the airport at the time $t_{\text {open }}$, according to which the actual departure time of aircrafts that perform ith flights $t_{i_{\text {DEPATRURE(fact) }}}$ is determined. In this case, the preparation of the aircraft for the flight is performed in accordance with the technological schedule, which is developed taking into consideration time in mind $t_{i_{D E P A R T U R E(f a c t)}}$, which involves re-planning the AGH.

To determine the effectiveness of the AGH system in a failure situation, we use the following indicators:

- $\quad V$ is the required amount of a set of resources that must be provided by the airport with timely maintenance of the aircrafts $P_{i}$ and DFP;

- $T_{\text {direct }_{i h}}$ is the duration of aircraft ground handling, which performs the ith flight using the $h$ complex of airport resources;

- $T_{\text {develop }_{h}}$ is the development of the $h$ complex of airport resources during the period of consideration of the emergency situation;

- $T_{\text {develop }_{V}}$ is the total development of all airport resources complexes of $V$ in servicing the aircraft.

- $P_{i}$ in the period of considering the emergency situation. In other words - the total duration of service of all flights provided by the DFP;

- $T_{\text {downtime }_{h}}^{1}$ is the absolute duration of downtime of the $h$ complex of airport resources in the period of consideration;

- $T_{\text {downtime }_{h}}^{2}$ is the duration of downtime of the $h$ complex of resources of the airport due to the total operating time of all sets of resources $V$;

- $K_{\text {develop }_{h}}^{1}$ is the coefficient of the $h$ complex development of resources of the airport due to the period of consideration;

- $K_{\text {develop }_{h}}^{2}$ is the coefficient of the $h$ complex development time of airport resources relative to the total operating time of all resource complexes $V$;

- $K_{\text {downtime }_{h}}^{1}$ is the downtime coefficient of the $h$ complex of resources of the airport according to the period of consideration;

- $K_{\text {downtim }}^{2}$ is the downtime coefficient of the $h$ complex of airport resources due to the total operating time of all airport complexes $V$;

- $m$ is the required number of units of each type of resources $f t h$, required for timely maintenance of the aircraft and the implementation of the DFP;

- $t_{\text {oper }_{i j}}$ is the duration of use of the $j t h$ resource unit while servicing of the personal computer which carries out the ith flight;

- $T_{\text {develop }_{j}}$ is the duration of use of the $j t h$ resource unit when servicing aircrafts in the period of consideration; 
- $T_{\text {develop }_{f}}$ is the total duration of use of the $f$ th type of resources in the maintenance of the aircraft in the period of consideration;

- $T_{\text {downtimg }}^{1}$ is the absolute downtime duration of the $j t h$ resource unit in the period of consideration;

- $T_{\text {downtime }}^{2}$ is the downtime duration of the $j t h$ resource unit due to the total duration of using the fth type resources;

- $K_{\text {develo } p_{j}}^{1}$ is the use factor of the $j$ th resource unit according to the period of consideration;

- $K_{\text {develop }_{j}}^{2}$ is the utilization factor of the $j t h$ unit of resource relative to the total duration of use of the fth type of resources;

- $K_{\text {downtime }}^{1}$ is the downtime coefficient of the $j t h$ resource unit according to the period of consideration;

- $K_{\text {downtime }}^{2}$ is the downtime coefficient of the $j$ th resource unit according to the total duration of using the $f$ th type of resources;

- $N_{\text {flightdelg }}$ is the amount of delayed flights;

- $t_{\text {delay }_{i}}$ is the delay time of $i t h$ flight, $\mathrm{h}$;

- $T_{\text {flightdelay }}$ is the total delay time of all flights, $\mathrm{h}$.

Failure situation is characterized by the use of the following parameters:

- $T_{\text {failuresituation }}$ is the duration of a failure situation, minutes

$$
T_{\text {failure }}=T_{\text {closed }}+T_{\text {departure }} ;
$$

- $T_{\text {closed }}$ is the duration of the period during which the airport was closed for the reception and departure of the aircrafts, minutes

$$
T_{\text {closed }}=t_{\text {departure }}-t_{\text {closed }} \text {; }
$$

- $T_{\text {solution }}$ is the duration of the period during which the solution of the failure situation was carried out,

$$
T_{\text {solution }}=t_{\text {timenorm }}-t_{\text {time of opening }},
$$

- $t_{\text {closure }}$ is the time (moment) of airport closure;

- $t_{\text {opening }}$ is the time (moment) of airport opening;

- $T_{\text {solution }}$ is the time (moment) of normalization of the airport in accordance with the established schedule of air traffic and flight plan [8].

After opening the airport, it is necessary to ensure the release of all delayed flights, which requires the involvement of additional resources to eliminate the emergency situation. It is obvious that in addition to the complex of resources $V$, which serve the aircraft in a failure situation, the airport must have additional complexes $d$. In this case, the process of functioning of the AGH system (Fig. 4) in the process of the liquidation of a failure situation is characterized by the following indicators:

- $V$ is the number of airport resource sets that are used during aircraft maintenance in a normal situation;

- $d$ is the additional amount of airport resources, which is used in the aircraft maintenance in a failure situation (in the process of liquidation);

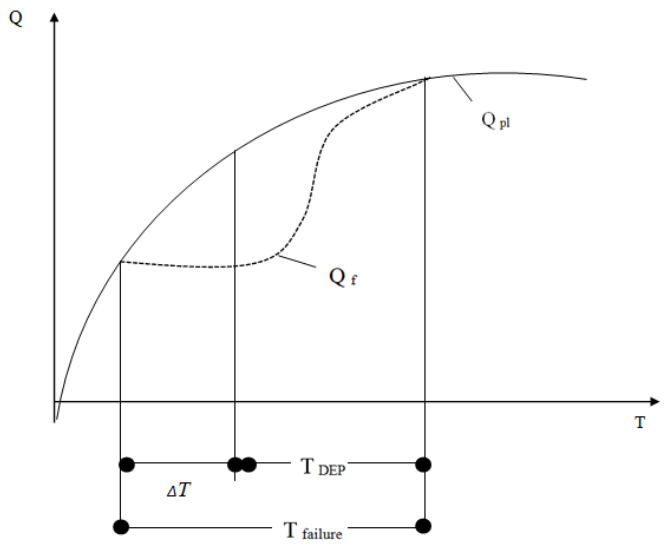

Fig. 4. Model of occurrence, development and liquidation of a failure situation in the AGH system's functioning:

$Q_{P L A N}$ is the amount of aircraft maintenance works, performed by the AGH system according to the production plan; $Q_{F A C T}$ is the amount of work on the aircraft maintenance, actually performed by the AGH system in the failure situation; $T_{\text {solution }}$ is the period during

which the failure situation was solved carried out (restoration of the characteristics of the AGH system);

$T_{\text {failuresituation }}$ is the duration of the failure situation

- $T_{\text {develop }_{d}}$ is the total development time for additional complexes of resources of the airport $d$, with the use of PC in an emergency situation (during its liquidation);

- $T_{\text {duration }_{\text {id }}}$ is the duration of using the resource complex $d$ in the proves of the aircraft maintenance, which the ith flight conducts [9].

To ensure the smooth operation of the AGH system, the implementation of the DFP and increase the level of regularity of aircraft flights, it is necessary to reduce the duration of the failure situation and the value of the associated parameters $T_{\text {failuresituation }}$. The decrease $T_{\text {solution }}$ is accompanied by an increase in the amount of airport resources used by the AGH system to eliminate the emergency situation. Obviously, the planning of AGH in 
emergency situations should be carried out in order to ensure the optimal amount of additional resources involved and the duration of recovery.

\section{CONCLUSIONS}

The processes of functioning of the AGH system are quite good for formalization and modelling, which in turn allows for operational planning and management of AGH. The use of simulation models of production processes at the airport allows you to justify the rationality of decision-making using quantitative indicators.

In turn, the established direction of the proposed simulation model encourages the creation of scientific and applied research direction: development of algorithms for automated operational control of the AGH on the bases of simulation modelling, software development that will allow comprehensive scheduling of airport production activities at the level of complex change manager.

\section{REFERENCES}

[1] Yu. V. Brusylo and T. Yu. Kramarenko, Peculiarities of the use of aviation ground equipment in operational aircraft maintenance. Works of National Aviation University, 46 (1), 2011. URL: https://doi.org/10.18372/2306-1472.46.2091/ science

[2] V. A. Koliasnykov, "Improving the technology of ground services to ensure trouble-free operation of the airport company," thesis of candidate dis. St. Petersburg, 2004. 24 p. (in Russian)
[3] E. V. Konikova, "Decision support system for operational management of $\mathrm{g}$ aircraft ground handling," Scientific Bulletin of Moscow State Technical University. no. 118, 2007, pp. 147-153. (in Russian)

[4] E. V. Konikova, "Perfection of methods of decisionmaking in an interactive mode by the dispatcher of system of complex operative management of aircraft ground handling," author's ref. dis. ... Cand. those. Science. St. Petersburg, 2009, 28 p. (in Russian)

[5] N. N. Sukhikh, "Prevention of the errors caused by the human factor, in operation of aircrafts with use of information and control systems," doctoral dissertation in technical sciences: 05.22.14. St. Petersburg, 1992, $348 \mathrm{p}$.

[6] M. V. Kharchenko, Model of technological processes of ground handling and transportation at the airport, Mykolaiv, 2015. no. 96. URL: http://www.globalnational.in.ua/archive/3-2015/96.pdf. (in Russian).

[7] D. Tabares and F. Mora-Camino, "Aircraft Ground Handling: Analysis for Automation," 17 th AIAA Aviation Technology, Integration, and Operations Conference. 2017. DOI:10.2514/6.2017-3425

[8] J. G. Ray, "Aircraft Ground Handling Characteristics as Required for Maximum Efficiency," $S A E$ Technical Paper Series, 1951. DOI:10.4271/510166

[9] T. Kazda and B. Caves, "Aircraft Ground Handling," Airport Design and Operation, 2010, pp. 173-196. DOI:10.1108/9780080546438-009

Received October 19, 2020

Shevchuk Dmytro. orcid.org/0000-0001-9911-7214. Doctor of Engineering Science.

Head of the Air Transportation Management Department, Professor.

Faculty of Transport, Management and Logistics, National Aviation University, Kyiv, Ukraine.

Education: National Aviation University, Kyiv, Ukraine, (2003).

Research area: methods of restoring the aircraft controllability in special situations in flight.

Publications: 135.

E-mail: dmitroshevchuk@gmail.com

Medynskyi Denys. orcid.org/0000-0002-8081-8712.

Post-graduate student. Assistant of the Air Transportation Management Department.

Faculty of Transport, Management and Logistics, National Aviation University, Kyiv, Ukraine.

Education: National Aviation University, Kyiv, Ukraine, (2017).

Research area: research of operations in transport systems, simulation modelling, decision making in failure situations.

Publications: 16.

E-mail: medynskyi_denys@ukr.net

Д. О. Шевчук, Д. В. Мединський. Імітаційна модель процесу оперативного обслуговування повітряних кораблів у збійних ситуаціях

У статті визначено стохастичні процеси, які мають за мету відбуватися в авіатранспортній системі. Виокремлено потік замовлень на обслуговування на який впливають: організаційні, метеорологічні та умови повітряного руху. Уточнено визначення поняття про те, що великий вплив на внутрішній стан системи НОПК здійснюється за рахунок випадкової тривалості обслуговування повітряного корабля, це в свою чергу призводить до того, що система наземного обслуговування повітряних кораблів не в змозі подолати дефіцит спецтехніки і виникає збійна ситуація. Розроблено імітаційну модель виникнення, розвитку та усунення збійної ситуації в аеропорту на основі методології розробки системи комплексного оперативного управління наземного обслуговування повітряних кораблів, яка дозволить у подальшому прогнозувати результати процесів наземного обслуговування. Таким чином, сформовано наукове завдання, щодо визначення алгоритмів імітаційного моделювання системою наземним обслуговуванням повітряних кораблів з вмінням вирішувати 
задачі раціонального розподілу ресурсів з урахуванням функціонування системи. Визначено науковоприкладний напрямок дослідження: побудова моделі функціонування системи наземного обслуговування повітряних кораблів в різних режимах: штатних, позаштатних, збійних; побудова технологічних графіків обслуговування повітряних кораблів в аеропорту під час: оборотного, початкового, транзитного, проміжного та після закінчення рейсів, ефективності функціонування системи відносно технологічних процесів за допомогою інформаційних ресурсів.

Ключові слова: імітаційне моделювання; збійна ситуація; позаштатна ситуація; наземне обслуговування повітряних кораблів; аеропорт; система; комплекс ресурсів.

Шевчук Дмитро Олегович. orcid.org/0000-0001-9911-7214. Доктор технічних наук. Професор. Завідувач кафедри. Кафедра організації авіаційних перевезень, Факультет транспорту, менеджменту і логістики, Національний авіаційний університет, Київ, Україна.

Освіта: Національний авіаційний університет, Київ, Україна, (2003).

Напрям наукової діяльності: методи відновлення керованості літака в умовах виникнення особливих ситуацій у польоті.

Кількість публікацій: 135.

E-mail: dmitroshevchuk@gmail.com

Мединський Денис Володимирович. orcid.org/0000-0002-8081-8712. Асистент, аспірант.

Кафедра організації авіаційних перевезень, Факультет транспорту, менеджменту і логістики, Національний авіаційний університет, Київ, Україна.

Освіта: Національний авіаційний університет, Київ, Україна, (2017).

Напрям наукової діяльності: дослідження операцій в транспортних системах, імітаційне моделювання, прийняття рішень у збійних ситуаціях, транспортні системи.

Кількість публікацій: 16

E-mail: medynskyi_denys@ukr.net

Д. О. Шевчук, Д. В. Мединский. Имитационная модель процесса оперативного обслуживания воздушных кораблей при сбойных ситуациях

В статье определены стохастические процессы, которые происходят в авиатранспортной системе. Отдельно выделен поток заказов на обслуживание, на которое влияют: организационные, метеорологические и условия воздушного движения. Уточнено определения понятия о том, что значительное влияние на внутренние состояние системы наземного обслуживания воздушных кораблей производится за счёт случайной длительности обслуживания воздушных кораблей, это в свою очередь, приводит к тому, что система наземного обслуживания воздушных кораблей не может преодолеть дефицит спецтехники и возникает проблемная ситуация. Разработана имитационная модель происхождения, развития и ликвидации проблемной ситуации в аэропорту на основании методологии разработки системы комплексного оперативного управления наземным обслуживанием воздушных кораблей, которая позволяет в дальнейшем прогнозировать результаты процессов наземного обслуживания. Таким образом, сформировано научное задание относительно определения алгоритмов имитационного моделирования системой наземным обслуживанием воздушных кораблей с умением решать задачи по рациональному распределению ресурсов с учетом функционирования системы. Определено научно-прикладное направление изучения: построение модели функционирования системы наземным обслуживанием воздушных кораблей в разных режимах: штатных, внештатных, поломок; построение технологических графиков обслуживания воздушных кораблей в аэропорту во время: оборотного, начального, транзитного, промежуточного и после окончания рейсов, эффективности функционирования системы относительно технологических процессов с помощью информационных ресурсов.

Ключевые слова: имитационное моделирование; сбойная ситуация; внештатная ситуация; наземное обслуживания воздушных кораблей; аэропорт, система; комплекс ресурсов.

Шевчук Дмитрий Олегович. orcid.org/0000-0001-9911-7214. Доктор технических наук. Профессор. Заведующий кафедрой.

Кафедра организации авиационных перевозок, Факультет транспорта, менеджмента и логистики, Национальный авиационный университет, Киев, Украина.

Образование: Национальный авиационный университет, Киев, Украина, (2003).

Направление научной деятельности: методы восстановления управляемости самолётом в условиях возникновения особой ситуации в полёте.

Количество публикаций: 135.

E-mail:dmitroshevchuk@gmail.com

Мединский Денис Владимирович. orcid.org/0000-0002-8081-8712 Ассистент, аспирант.

Кафедра организации авиационных перевозок, Факультет транспорта, менеджмента и логистики,

Национальный авиационный университет, Киев, Украина.

Образование: Национальный авиационный университет, Киев, Украина, (2017).

Направление научной деятельности: исследование операций в транспортных системах, имитационное моделирование, принятие решений в сбойных ситуациях, транспортные системы.

Количество публикаций: 16.

E-mail: medynskyi_denys@ukr.net 